\title{
Paideusis
}

\section{Newman: A Hundred Years Later}

\section{Paul T. O'Leary}

Volume 3, Number 2, 1990

URI: https://id.erudit.org/iderudit/1073395ar

DOI: https://doi.org/10.7202/1073395ar

See table of contents

Publisher(s)

Canadian Philosophy of Education Society

ISSN

0838-4517 (print)

1916-0348 (digital)

Explore this journal

Cite this document

O'Leary, P. (1990). Newman: A Hundred Years Later. Paideusis, 3(2), 2-2.

https://doi.org/10.7202/1073395ar

(C) Paul T. O'Leary, 1990

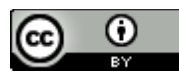

This document is protected by copyright law. Use of the services of Érudit (including reproduction) is subject to its terms and conditions, which can be viewed online.

https://apropos.erudit.org/en/users/policy-on-use/ 


\section{Newman: A Hundred Years Later}

Born near the beginning of the nineteenth century, John Henry Newman died on the evening of August 11,1890, after a life that was rich, varied, and filled with controversy. A master of English prose, Newman's writings cover philosophy, theology, apologetics, history, as well as poetry and two novels. It is, however, as an educational thinker that this quintessential nineteenth century English gentleman stands as the focal point for this issue of Paideusis.

Along with his Apologia Pro Vita Sua, Newman's Idea of a University still remain easily available to the reading public. Where the Apologia is an essay in self-justification, Newman's Idea is a justification of a particular vision of university education. For Newman, the university is neither a research institute nor a training ground for careers, but rather has as its goal the enlargement of minds. These and many other of Newman's ideas sparked controversy in his own time and, no doubt, continue to do so since their relevance is still felt a hundred years later.

Paul T. O'Leary, Editor 